\title{
PUBLIC HEALTH SIGNIFICANCE OF UNFULFILLED HEALTH NEEDS OF THE POPULATION OF SERBIA
}

\author{
Khoitar Samir, ${ }^{1}$ Simic Svetlana, ${ }^{2}$ Jevtovic Obradovic Ivana, ${ }^{2}$ Janicijevic Katarina ${ }^{3}$ \\ ${ }^{1}$ Health Center Nova Varos, Serbia \\ ${ }^{2}$ Health Center Cacak, Serbia \\ ${ }^{3}$ University of Kragujevac, Faculty of Medical Sciences, Department of Social Medicine, Kragujevac, Serbia \\ Primljen/Received 21. 08. 2020. god. \\ Prihvaćen/Accepted 21. 09. 2020. god.
}

\section{To the Editor,}

Health care is a comprehensive and organized activity of society in preserving and improving the health of citizens and families. It represents society's response to unplanned and unpredictable events that endanger the health and ensure levels of health and the causes of illness. The availability of public health is determined by various factors that relate to both the patient and the health system. Health insurance coverage, coverage in staff, space, equipment and financial resources, scheduling and referral systems, quality of services provided, and continuity of health care are factors of the health system that can affect the availability of health care. However, factors such as age, socioeconomic status, previous experiences with health services, perceptions of the quality of public health, and health literacy constitute the characteristics of the individual, which may also influence their decisions to provide health care (1). One of the socio-economic aspects of health is unequal aging health care (2). A key indicator for monitoring a degree of inequality in health care, and through the approach, use, and realization of health care, is the satisfaction or dissatisfaction of clients (3). Unmet needs represent diversity in the provision of health services: needs that are considered necessary and essential for the care of specific health issues (4). Unmet public health needs affect people's health and quality of life. They can also directly alter mortality risks and/or be indirectly linked to the statuses of several psychosomatic and psychiatric illnesses today $(5,6)$. Numerous factors related to real unmet health needs are reflected in gender, age, lack of insurance, education, unemployment, low wages, and more. All of the above points to unequal access to health care from a socio-economic point of view. The characteris- tics of the health care system, such as the number of doctors or dentists, the method of payment of primary health care doctors, and the amount of money for outof-pocket services, also have a severe impact on unmet health care needs. The results of many studies show that the frequency of unmet medical or dental needs varies significantly from country to country, which can be partly explained by differences in health care financing (6). Since inequalities in access and usage of health services are some of the determinants of health (socioeconomic, etc), public policymakers must identify these determinants to understand the specific barriers that health care users are faced with, in terms of physical, geographical, cultural, and financial accessibility of the health care (7).

Identifying such barriers is a crucial indicator for measuring health inequalities at both local and national levels (8).

The results of research conducted in neighboring countries show that: reasons for non-fulfillment of health achievements are lack of necessary financial resources, the inadequate expectation of a scheduled medical examination, a greater distance of residence from health care providers with a frequency of (about) $13 \%$ in Montenegro, $108 \%$ in Macedonia, $8 \%$ in Croatia, and $0.5 \%$ in Slovenia (9). In many EU countries, unmet health care needs have nearly doubled from $5.26 \%$ to $9.99 \%$, while in other there has been a significant increase of $15 \%$ (10). There has also been a growth expressed as a percentage of people reporting unmet health needs in the United States and Canada. Rates of unmet public health needs in the United States are higher (5-20\%) compared to the same in Canada (4-12\%), (11). In New Zealand, $16.5 \%$ of respondents in primary public health missed a visit to a general practitioner due to costs, while $9.3 \%$ reported unmet 
health needs in secondary healthcare (12). Research related to the prevalence of unmet health needs in a survey of (around) 13760 citizens of Serbia, conducted by the Ministry of Health of the Republic of Serbia in 2013, showed that the biggest obstacles to meeting the needs of health care in this population group are due to financial reasons $(20 \%)$, long wait for an appointment with a doctor $(8 \%)$, and problems with transportation to a remote place where health care is provided (5\%). The biggest obstacles in achieving health care relate to dental $(13.5 \%)$, general health care $(13 \%)$, prescribing necessary medications $(11 \%)$, and care for patients with altered and impaired mental health (2.5\%) (13). The estimated number of people with unmet health needs in our country indicates that significant changes in health policy are necessary. The fact is that various barriers prevent people from accessing existing health services. In Serbia and the other countries in transition, demographic and socioeconomic inequalities in health care have not been realistically and sufficiently studied. Public health policies do not receive the necessary

\section{REFERENCES}

1. Janković J, Simić S. [The association of demographic and socioeconomic determinants and self-perceived health]. Srp Arh Celok Lek. 2012; 140(1-2): 77-83. Serbian. doi: 10.2298/ sarh1202077j.

2. Pappa E, Kontodimopoulos N, Papadopoulos A, Tountas Y, Niakas D. Investigating unmet health needs in primary health care services in a representative sample of the Greek population. Int J Environ Res Public Health. 2013; 10(5): 201727. doi: 10.3390/ijerph10052017.

3. Karanikolos M, Kentikelenis A. Health inequalities after austerity in Greece. Int J Equity Health. 2016; 15:83. doi: 10.1186/s12939-016-0374-0.

4. Kertesz SG, McNeil W, Cash JJ, Desmond R, McGwin G Jr, Kelly J et al. Unmet need for medical care and safety net accessibility among Birmingham's homeless. J Urban Health. 2014; 91(1): 33-45. doi: 10.1007/s11524-013-9801-3.

5. Detollenaere J, Hanssens L, Vyncke V, De Maeseneer J, Willems S. Do we reap what we sow? Exploring the association between the strength of european primary healthcare systems and inequity in unmet need. PLoS One. 2017; 12(1): e0169274. doi: 10.1371/journal.pone.0169274.

6. Lu L, Zeng J, Zeng Z. What limits the utilization of health services among the china labor force? Analysis of inequalities and sufficient social attention. Reducing disparities in health and health care is a crucial precondition for the future evolution of health systems and their institutions (13).

The health needs of the entire population, which are unmet in the health system, represent a significant challenge for any health system. Therefore, more detailed analyzes in the future and revealing the factors that are related to them are important for creating health policies that would contribute to reducing inequalities in access, use, and realization of health care needs.

Acknowledgment: None.

Conflict of Interests: The authors declare that there are no conflicts of interest related to this article.

\section{Funding: None}

\section{Licensing}

This work is licensed under a Creative Commons Attribution 4.0 International (CC BY 4.0) License.

in demographic, socio-economic, and health status. Int J Equity Health. 2017; 16(1): 30. doi: 10.1186/s12939-017-0523-0.

7. Papanikolaou V, Zygiaris S. Service quality perceptions in primary health centers in Greece. Health Expect. 2014; 17(2): 197-207. doi: 10.1111/j.1369-7625.2011.00747.x.

8. Lee SY, Kim CW, Kang JH, Seo NK. Unmet healthcare needs depending on employment status. Health Policy. 2015; 119(7): 899-906. doi: 10.1016/j.healthpol.2014.09.007.

9. Ko H. Unmet healthcare needs and health status: Panel evidence from Korea. Health Policy. 2016; 120(6): 646-53. doi: 10.1016/j.healthpol.2016.04.005.

10. Zhu Y, Osterle A. Rural-urban disparities in unmet longterm care needs in China: The role of the hukou status. Soc Sci Med. 2017; 191: 30-7. doi: 10.1016/j.socscimed.2017.08.025.

11. Hlebec V, Srakar A, Majcen B. Determinants of unmet needs among slovenian old population. Zdr Varst. 2015; 55(1): 78-85. doi: 10.1515/sjph-2016-0011.

12. Bagshaw P, Bagshaw S, Frampton C, Gauld R, Green T, Harris C, et al. Pilot study of methods for assessing unmet secondary health care need in New Zealand.. N Z Med J. 2017; 130(1452): 23-38.

13. Mitrasevic M, Radovanovic S, Radevic S, Maricic M, Zivanovic Macuzic I, Kanjevac T. The unmet healthcare needs: evidence from Serbia. Iran J Public Health. 2020; 49(9): 16508. doi: 10.18502/ijph.v49i9.4081.

\section{Correspondence to/Autor za korespondenciju}

Katarina M. Janicijevic

University of Kragujevac, Serbia, Faculty of Medical Sciences, Department of Social Medicine

Svetozara Markovica 69, 34000 Kragujevac

e-mail:kaja.andreja@yahoo.com

How to cite this article: Khoitar S, Simic S, Jevtovic Obradovic I, Janicijevic K. Public health significance of unfulfilled health needs of the population of Serbia. Sanamed.2021;16(3): 235-236 